\title{
Public Policy and Program Administration in the Philippines: A Critical Discourse
}

\author{
Mark M. Alipio a,b \\ April 2020 \\ ${ }^{a}$ Davao Doctors College, General Malvar St., Davao City 8000, Philippines \\ ${ }^{b}$ University of Southeastern Philippines, Mintal, Davao City 8000, Philippines
}

\begin{abstract}
This study was conducted to explore and describe the current public policy and program administration in the Philippines. The approaches, roles, scope, practice, contributions, and discipline of public administration was first discussed, followed by the history, heritage, and hubris of the Philippine public administration. Issues such as identity crises were revisited, as well as in specific problems in Government Owned and Controlled Corporations. Finally, the nature and state of local government of the Philippines were elucidated.
\end{abstract}

Keywords: Government, Philippines, Program Administration, Public Administration, Public Policy

\section{Approaches, Roles and Scope of Public Administration}

Chand and Chakrabarty (2012) contended that public administration is a generalized human activity, concerned with the ordering of men and materials required to achieve collective social ends. In an attempt to define the different aspects of public administration, these are described in nine relatively distinct approaches that grow out of the different perspectives that shape its structures and functions. These are institutional approach which emphasizes formal relationships and the separation of powers among the three branches of the government, the structural approach which sees public administration as a non-political and a purely technical organization based on certain scientific principles, behavioral approach which applies the knowledge of social psychology, anthropology, psychology and many other disciplines in an effort to secure a better understanding of the actual human behavior within organizations, system approach which views public administration as a system of interrelated and interdependent parts and forces where demands from the people are considered as inputs and the goods and services rendered by the government are the outputs, ecological approach which views public bureaucracy as a social institution which is continuously interacting with the economic, political, and sociocultural sub-systems of a society, comparative approach in which the administrative structures of different nations are compared with the different cultural settings, the public policy which is concerned with the public and their problems, to shape the society for its betterment, the political economy approach which deals with the application of economic methods to political problems like the influence of elections on the 
choice of economic policy and the public-choice approach which is a method to study the decisional processes for the allocation of scarce resources in the society where the actions of the government should be consistent with the values and interests of its citizens.

Sri, Jipson \& Paul (2011) articulated that there are two divergent views regarding the nature of Public Administration. These are the managerial view which involves only the work of those engaged in performing managerial functions in an organization, namely, (POSDCORB): $\mathrm{P}$ - Planning, $\mathrm{O}$ - Organizing, S - Staffing, $\mathrm{D}$ - Directing, CO - Coordinating, $\mathrm{R}$ - Reporting, and B - Budgeting and integral view which sees public administration as the sum total of the manual, clerical and managerial activities.

There are two scopes of public administration: traditional and modern views. The traditional writers restrict the scope of public administration to the executive branch of the government. The modern writers have extended the scope of public administration to all the three branches of the government. According to them, public administration is the whole government in action. They argue that the activities of the legislature and the judiciary also affect and shape the functioning of public administration considerably. Thus, the study of public administration includes the activities of the executive branch as well those aspects of the legislative and judicial activities that have considerable impact on the functioning of public administration.

\section{Public Administration as a Field of Study, Art, Science, Discipline, and Practice}

Woodrow Wilson, the Father of Public Administration, advocated four concepts in his essay The Study of Public Administration (1887) which are the separation of politics and administration, the comparative analysis of political and private organizations, improving efficiency with business-like practices and attitudes toward daily operations, and improving the effectiveness of public service through management and by training civil servants, merit-based assessment. In this report, Public Administration as a field of study, art, science, discipline, and practice were discussed. As a field of study, it focuses on the history, hows, whats, and whys of Public Administration. As a field of art, it invokes the creative side of the public servant, whereas as a science, it is mostly concentrated on the technical aspects of the topic. As a discipline, it has five branches and finally, as a field of practice, it encapsulates all of the previously mentioned topics and applies those learnings into the practical field of Public Administration.

\section{Contributions of the Perspective of Public Administration}

Cariño (1975), in her Journal, "Bureaucratic Norms, Corruption and Development", gives the following types of bureaucratic norms:

1. The first type covers universalistic norms. These are norms that regard parochial considerations as primary, and many citizens, for their part, will seek out a friend before transacting business in an office or finding none, will then go to an intermediary who does know 'somebody there.

2. The second is a variant of the first, but with time as a salient factor. It may be called simply priority norms. Since everyone is treated equally, an important organizational rule is: "first come, first served." A bureaucratic would not give a latecomer any preference except in 
special cases. Thus, patients wait for their turn in a clinic, but the queue is disregarded when an emergency case is brought in. This implies that the bureaucrat is not a machine and can make alternative decisions in the light of the problem at hand. However, there are also accepted criteria which would justify deviations without exposing the bureaucrat to charges of corruption or favoritism.

3. The third includes efficiency norms. A bureaucrat is supposed to deliver the service in as little time and with as little cost to the public as possible. However, he may delay service through absenteeism or malingering, by losing relevant papers, by improper information to clients as to what are needed, and through other conscious or unwitting forms of ineffectual work.

4. The fourth type has to do with the use of a person's skill or professional training in serving a client. The customs agent who describes gold jewelry as brass - whether by honest mistake or collusion with the importer - is guilty of violating a technical norm. The first three norms are applicable throughout the bureaucracy but the relevant technical norm would depend on the function of the person in question. If a person is employed as a guard and performs the duties of an assessor - perhaps to reduce the tax of a friend, then he has gone against jurisdictional norms. In that case, he is not qualified to evaluate the commodity technically and cannot strictly be bound by professional standards. Employees over-reaching their functional boundaries are not uncommon.

\section{Public Administration in the Philippines: History, Heritage and Hubris}

The Public Administration in the Philippines comes from the different colonial regimes and idiosyncrasies of Filipino ethos. It is a blend of western and indigenous practices and culture. It is a result of an agreement between the United States Technical Assistance Program and the Philippine Government through the technical cooperation of the University of Michigan to professionalize the government service.

Conscious of maintaining both "quality and relevance", responding to the changing demands of its clientele, and reflecting developments in the field of public administration, the Philippine program has instituted the following changes: an emphasis on technique and technique-cum-practicum courses; the introduction of new specialization in the MPA curriculum, namely, Public Policy and Program Administration; the merging of organization and management and personnel management into the single field of organizational studies, thus, reducing the areas of specialization in the MPA curriculum from five to four: fiscal administration, public policy and program administration, local government and regional administration, and organization studies; offering of the mid-career program designed for people holding mid-career or supervisory positions; and offering of a new Diploma in public Management to give administrators an opportunity to pursue training in public administration without having to pursue a longer master's degree program. 


\section{The Identity Crisis in Public Administration Revisited: Some Definitional Issues and the Philippine Settings}

The identity crisis of Public Administration is really a problem on the American field of thought. This was due to the fact that American Public Administration had its beginning in the discipline of Political Science. In 1948 D. Waldo, citing John M. Gaus, reflected on the direction and thrust of Public Administration as a field of study. He noted that students of Public Administration have become more uncertain as to the ends, aims and methods of Public Administration which they should advocate. The dilemma inquires into the nature and definitional premises of the field where its theoretical postulates and principles are concerned. In 1968, issue on determining the scope, nature and boundaries of the field, including the methods of studying and teaching it emerged. The term "Identity Crisis" on Public Administration came out of being.

In the Philippine setting, the "Identity Crisis" on Public Administration never existed. This is due fact that Public Administration has maintained some disciplinary independence from allied discipline and has not been insecure with Political Science. The Politics-Administration Dichotomy has no strong tradition and is not applicable here. And that the peculiarities of a developing country have necessitated Philippine Public Administration to give emphasis on or favor to service type researches. The identity crisis is a problem that belongs to the United States' Public Administration and not to the Philippines. The burden of overcoming the identity crisis in the Philippines becomes not only a question of deriving disciplinary boundaries as to prescribing normative valuations for Public Administration at a universal, high-ordered level but on defining an indigenous philosophy for teaching and practicing Public Administration in the country. The Identity Crisis cannot and should not be narrowly viewed from Western Standards. The Identity Crisis should be viewed from the perspective of development administration or from a field now called Development Public Administration. Develop research programs that focuses on the problems in the country, looking into the behavioral insurance of politics and administration, and the accompanying features that open the government to development process.

\section{Government Owned and Controlled Corporations (GOCCs) (Issues, Problems, and Policy Dilemmas)}

The creation of the GOCCs was a necessity to bring about an equilibrium in the environment of private enterprise and to bring closer to the people government services that were otherwise unreachable to a wider spectrum of society. GOCCs primarily exist to satisfy public needs which is widely different from that of a private corporation which was created primarily for the creation of profit but GOCCs also function to bring about needed revenues for the government. The disastrous financial performance of the GOCCs in mid 50s and 60s was widely attributed to incompetence, graft and corruption and financial mismanagement. The growth of the number of GOCCs during the first 10 years of the Marcos regime was brought about by the need for the national government to pursue wide ranging infrastructure projects all throughout the archipelago. These were the glory days of the GOCCs wherein employees 'salaries, wages and benefits differ largely from that of government line agencies more so with their counterparts in the LGUs. GOCCs reached its peak t0 303 in 1984 during the Marcos regime. The downside was in the pursuit of the so-called socio-economic development under Marcos' New Society Philippines' external debt ballooned to 22 billion dollars in 1982 from 7 billion dollars in 1977. Worst, some of these GOCCs exist to serve as milking cows for some of its cronies and majority of these GOCCs had actually a duplication of function with other GOCCs. These GOCCs were created for the purpose of political accommodation for its supporters and cronies. FM Jr. once served as PHILCOMSAT president with a 21,000-dollar salary per month when such company was in the doldrums. 
The late 1980s and 1990s saw a new chapter in the existence of GOCCs. As per advice by the IMF/WB the governments of Cory and FVR joined GATT. Thus, the need for government to embark on programs that tackle devolution, decentralization, peso devaluation and privatization in order to spur wide-ranging socioeconomic development, to attract investors and encouraged competition. Thus, the national government had to privatize some of its crown jewels. PAL, PLDT, San Miguel, Meralco, NPC and National Steel were among the companies in which substantial government shares were auctioned off to private corporations, local and international. However, the unabated growth of GOCCs still continue especially during Arroyo's time. By the time her term ended in 2010, there were 604 GOCCs and 446 of which were operational water districts. This was primarily due to the absence of an effective monitoring system to supervise the activities of GOCCs.

The passage of Executive Order no. 936, which created the GCMC (Government Corporate Monitoring Committee) and Presidential Proclamation no. 50 addressed the issues concerning GOCCs. P.D. No. 50 in particular authorized GOCC privatization. Thus, GOCCs were reduced to 158 from 604 in 2010.

But what really addressed comprehensively the issues, concerns and policies of GOCCs was the passage of the GOCC Governance Act of 2011 (R.A. no. 10149). This law rationalizes the GOCC sector and created the GCG (Governance Commission for GOCCs). This body has the power/function to ascertain whether a GOCC should be: reorganized; merged; streamlined; abolished; or privatized. As of late through the recommendation of the GCG, President Duterte through an executive order abolished the Phil. Sugar Corporation (PHILSUCOR). Established in 1983 to provide financial assistance to sugar cane farmers according to GCG had already outlived its primary function as it already duplicated the function of the Land Bank of the Philippines and other government GFIs in giving financial assistance to farmers. Furthermore, COA found out in 2017, that it released money amounting to 203 million pesos not to sugar cane farmers directly but to capitalists with businesses not related to sugar. Gone really are the glory days of the GOCC with the passage of R.A. no. 10149.

The role of government embarking on a wide-ranging socio-economic development instead of the private sector taking the lead especially in the early 1970s could be attributed to the Development Administration model or Development management model or Postcolonial Development model. Governments veered away from the rigid practice of the Colonial Bureaucratic Model in the pursuit of wide-ranging socio-economic development programs such as economic growth, poverty eradication, income generation, national building and so on. It is an administrative system that was expected to enhance socio-economic growth progress in postcolonial developing countries (Haque 2007 page 8, Theory and Practice of Public Administration in Southeast Asia) Government undertaking various socio-economic activities necessitated the creation of GOCCs to handle the multitude of tasks of such undertaking. However, this also contributed to an unabated growth of GOCCs which in the long run required the passage of laws to rationalize the operations of the GOCCs.

In recent times, government adopted the NPM (New Public Management) model in its approach to socioeconomic development. In this manner, government partnered with the private sector in undertaking critical infrastructure projects through the so-called Public-Private-Partnership. Recent PPP projects include the new Mactan International Terminal. NPM model allows government to be the impetus in providing the favorable environment for private sector participation in the pursuit of the common goal of socio-economic development. 


\section{Nature and State of Local Government in the Philippines}

United Nations (1966) defines local governments as subordinate entities, having no inherent powers and must look up to the higher governmental level for delegation of authority. Furthermore, these are "geographic subdivisions"; or restricted geographic areas, dealing with those matters which concern the people living in a particular locality. Two important elements are found in any definition of local government: the presence of a higher authority and territorial boundary. According to the United Nations (1966), while local governments do not have inherent powers, they do have legal authority to exercise their powers.

The existence of several layers of local governments in the Philippines may be attributed to its geographic peculiarities, centralist experience and the historical basis of its barangays. The International Union of Local Authorities (2016) noted that the number of layers of local government depends on: geography, number of basic units, degree of centralization and population. The power to create municipal corporations "is inherent in sovereignty." In the Philippines, the power is vested in the legislature. Thus, Congress by law creates LGUs, although plebiscite among the affected residents is a pre-requisite before actual operation. According to Maas (1959), editor of Area and Power, local government is presented as a manner of dividing power by area or authority. He pointed out that the creation of local government units is "advantageous for the promotion of rural development". Local governments are a means of providing self-identity, especially in ethnically homogenous communities.

\section{References}

United Nations (1966). Local Government Personnel Systems. Michigan, United States: United Nations, Public Administration Branch. Sri, Jipson \& Paul (2011). Public Administration: Theory and Practice

Reyes, Danilo R., The Identity Crisis in Public Administration Revisited: Some Definitional Issues and the Philippine Settings. Philippine Journal of Public Administration, vol. XX111, no. 1 (Jan., 1979) retrieved from http: //lynchlibrary.pssc.org.ph:8081/bitstream/

Reyes, Danilo N. “ The Identity Crisis in Public Administration Revisited: Some Definitional Issues in the Philippine Setting”, Philippine Journal of Public Administration: p. 28, January 1979

Reyes, Danilo N. (1995). "Public Administration in the Philippines: History, Heritage and Hubris", p. 39-59

Prof. Ledivina Cariño (1975), Ethics in Politics: A Review and Syntheses of Literature

Pilar, Nestor N., "Philippine Public Administration: From Classical to New Public Administration to New Public Management', Philippine Journal of Public Administration, Vol. LII Nos. 2-4: p.309-311, April-October 2008

Maas, Arthur (1959), ed. Area and Power: A Theory of Local Government. Glencoe, III.: Free Press.

International Union of Local Authorities (2016). Executive Order No. 351, s. 2004 | GOVPH. Official Gazette of the Republic of the Philippines. Retrieved 2016-12-21.

Endriga, Jose N. "The Historical Background of the Discipline of Public Administration", p. 123

Chand, P. \& Chakrabarty, B. (2012), Public Administration in the Globalizing World: Theories and Practices.

Brilliantes, Alex Jr. and Fernandez, Maricel. "Is there a Philippine Public Administration?Or Better Still, For Whom is the Philippine Public Administration?", A paper presented in the public colloquium on: Is there a Philippine Public Administration: A Timeless Issue, June 26-27, 2008, UP National College of Public Administration and Governance (UP NCPAG). p.13-14

Alipio, M. M. (2020). Predicting Academic Performance of College Freshmen in the Philippines using Psychological Variables and Expectancy-Value Beliefs to Outcomes-Based Education: A Path Analysis.

Alipio, M. M. (2020). Chest Radiographic Findings of Patients Infected with 2019-nCOV. Chest.

Alipio, M. M. (2020). Challenges and Strategies for Curbing the 2019-nCOV Pandemic: The Case of the Philippines.

Alipio, M. M. (2020). Academic Adjustment and Performance among Filipino Freshmen College Students in the Health Sciences: Does Senior High School Strand Matter?

Alipio, M. M. (2020). 2019-nCOV Scare: Situation Report, Role of Healthcare Professionals and Clinical Findings. 